\title{
A Remarkable new Species of Cheilolejeunea (MARChantiophyta: LeJeuneaceAe) From Colombia
}

\author{
S. ROBBERT GRADSTEIN ${ }^{1}$ and M. ELENA REINER-DREHWALD ${ }^{2}$
}

\begin{abstract}
Summary: We describe the new liverwort species Cheilolejeunea schiavoneana M.E.Reiner \& Gradst. from submontane rainforest in the Western Cordillera of Colombia. The new species is related to $C$. adnata (C. sect. Cheilolejeunea) but differs by larger plant, leaf and underleaf size, robust stems, a 5-6 cells wide ventral merophyte, abundance of microphyllous branches, and vegetative reproduction by caducous leaf lobes produced on flagelliform shoots. The latter feature is characteristic of the genus Rectolejeunea and its presence in Cheilolejeunea is apparently a case of parallel evolution. The discovery of $C$. schiavoneana adds a further endemic taxon to the rich flora of the Colombian Western Cordillera.
\end{abstract}

Key words: Cheilolejeunea adnata; Cheilolejeunea schiavoneana; Cheilolejeunea section Cheilolejeunea; Colombia; liverworts; morphology; taxonomy; Western Cordillera of Colombia.

\begin{abstract}
Resumen: Cheilolejeunea schiavoneana (Marchantiophyta: Lejeuneaceae), una nueva especie de Colombia. Se describe la nueva especie Cheilolejeunea schiavoneana M.E.Reiner \& Gradst., coleccionada en selva submontana de la Cordillera Occidental de Colombia. Este nuevo taxon está relacionado con $C$. adnata (C. sección Cheilolejeunea) pero difiere en el mayor tamaño de las plantas, hojas y anfigastrios, el ancho del merofito ventral (de 5-6 células), la abundancia de ramas microfilas, y la reproducción vegetativa por medio de lobos caducos producidos en tallos flagelíferos. Esta última propiedad es característica del género Rectolejeunea, y su presencia en Cheilolejeunea es aparentemente debida a evolución paralela. El descubrimiento de C. schiavoneana agrega otro taxon endémico a la gran diversidad de la flora en la Cordillera Occidental de Colombia.
\end{abstract}

Palabras clave: Cheilolejeunea adnata; Cheilolejeunea schiavoneana; Cheilolejeunea sección Cheilolejeunea; Colombia; hepáticas; morfología; taxonomía; Cordillera Occidental de Colombia.

\section{INTRODUCTION}

The Western Cordillera of the Andes of Colombia is a rich area for liverworts (Gradstein \& Uribe, 2016). It is home to several rare or endemic species including Drepanolejeunea pterocalyx (Herzog) Bischl., Fuscocephaloziopsis pulvinata (Steph.) Fulf., Lejeunea drehwaldii Heinrichs \& Schäf.-Verw. (= Sphaerolejeunea umbilicata Herzog), Lepidozia pinnaticruris

\footnotetext{
${ }^{1}$ Muséum National d'Histoire Naturelle, Departement Systématique et Evolution, C.P. 39, 57 rue Cuvier, 75231 Paris cedex 05, France; email: gradstein@mnhn.fr

${ }^{2}$ Department of Systematics, Biodiversity and Evolution of Plants (with Herbarium), Albrecht von Haller Institute for Plant Sciences, Georg August Universität Göttingen, Untere Karspüle 2, 37073 Göttingen, Germany; email: mreiner@uni-goettingen.de
}

Steph., Lepidolejeunea grossepapulosa (Steph.) Piippo, Micropterygium longicellulatum Uribe \& E.L.Linares, Neesioscyphus allionii Steph., Plagiochila fastigiata Lindenb. \& Gottsche, Plagiochila rudischusteri H.Rob., Prionolejeunea arguta (Nees) Steph., P. magnistipula Herzog and Radula involvens Spruce, and is the diversity center of the genus Prionolejeunea (Spruce) Schiffn. with ca. $40 \%$ (10 spp.) of all Prionolejeunea species occurring in the area (Ilkiu-Borges, 2016).

Here we describe a remarkable new species in the genus Cheilolejeunea (Spruce) Steph. from the Western Cordillera of Colombia. Cheilolejeunea is one of the largest genera of the liverwort family Lejeuneaceae, with a wide distribution throughout the Tropics and well into the temperate regions of the Southern Hemisphere. The main diagnostic feature of the genus is the distal hyaline papilla 
on the leaf lobule; other important characters include: 1) ventral merophyte 2-12 cells wide; 2) leaf margins usually entire; 3 ) leaf cells often with large trigones and without intermediate thickenings; 4) oil bodies few per cell, large, coarsely granular (rarely finely granular); 5) ocelli usually absent; 6) lobules never reduced; 7) underleaves undivided or bifid, with upright lobes; 8) vegetative reproduction rare, by caducous leaf-lobes; 9) spores ornamented by numerous rosettes $(>10) ; 10)$ abundance of striatene-type sesquiterpenes and scarcity of flavonoids.

The circumscription of the genus was recently expanded based on molecular studies (Wilson et al., 2007; Schäfer-Verwimp et al., 2014; Ye et al., 2015), which showed that several well-known genera of Lejeuneaceae, e.g. Aureolejeunea R.M.Schust., Leucolejeunea A.Evans, Cyrtolejeunea A.Evans, Cystolejeunea A.Evans, Omphalanthus Lindenb. \& Nees and Trachylejeunea (Spruce) Steph., are part of Cheilolejeunea. As a result, the number of species assigned to the genus has risen to almost two hundred, in at least nine sections (Söderström et al., 2016; Ye et al., 2015). However, the real number of species in Cheilolejeunea may be much lower as the genus has not been monographed.

An unusual species of Cheilolejeunea, which appears to be undescribed, was detected by the second author among the collections made by the first author in the framework of an exploration of the bryophyte flora of the everwet rainforests along the Pacific coast of Colombia (Frahm, 1994). The species differs from all members of the genus Cheilolejeunea by modified caducous leaf lobes produced on specialized flagelliform branches. It is our pleasure to dedicate this new species to Dr. María Magdalena (Magui) Schiavone, in honor of her important contributions to the bryology of South America.

\section{Results}

Cheilolejeunea schiavoneana M.E.Reiner et Gradst., sp. nov. Fig. 1.

Diagnosis. Plants 1.8-2.45 mm wide, irregularly 1-2-pinnate, with numerous microphyllous branches. Stems rigid, of 11-15 rows of epidermis cells and 20-25 rows of much narrower medullary cells, all stem cells slightly thick-walled; ventral merophyte on main stems 5-6 cells wide. Leaf apex rounded. Leaf cells large, 25-40 × 20-30 $\mu \mathrm{m}$ in midleaf, conspicuously smaller towards the margin, walls with triradiate trigones; ocelli not observed. Lobules shortly flask-shaped, 1/6-1/5 × leaf length, fully inflated, tooth long and sharp, lobule cells much smaller than leaf lobe cells. Underleaves broadly ovate, $2.5-3 \times$ stem width, distant, bifid to 1/2, margins entire; ocelli not observed. Caducous leaves smaller than normal leaves, produced on short upright, flagelliform shoots, margins of caducous leaves with short rhizoids; underleaves on flagelliform branches imbricate, otherwise similar to normal underleaves.

Type. Colombia. Departamento Risaralda: western side of the Cordillera Occidental, municipio Mistrato, along the trail from Jeguadas to Puerto de Oro, ca. $5^{\circ} 45^{\prime} \mathrm{N} 76^{\circ} 01^{\prime} \mathrm{W}$, on canopy branches in submontane rainforest, $1200 \mathrm{~m}, 27$ July 1992, S.R. Gradstein 8591 (Holotype COL; Isotype GOET).

Plants to 2(-3) cm long, rather robust, 1.2-2.45 mm wide on stems, pale brown when dry, prostrate, irregularly and rather densely 1(-2)-pinnate, branches Lejeunea-type, frequently rather short and microphyllous with reduced leaf-lobes, microphyllous branches $0.3-0.4 \mathrm{~mm}$ wide. Stems $130-210 \mu \mathrm{m}$ in diameter, pale brown, rigid, made up of 11-15 rows of epidermis cells $(20-32 \times 25$ $38 \mu \mathrm{m})$ surrounding $20-25$ rows of much narrower medullary cells $(12-15 \times 17-20 \mu \mathrm{m})$, all stem cells slightly thick-walled; ventral merophyte 5-6 cells wide on main stems, 3-4 cells wide on branches. Leaves rather widely spreading, imbricate, leaf lobes convex, asymmetrically ovate with arched dorsal margin and \pm straight ventral margin, not falcate, $0.7-1.35 \mathrm{~mm}$ long $\times 0.65-1.1 \mathrm{~mm}$ wide, leaf surface smooth, apex broadly rounded, plane or recurved, margins entire, plane or dorsal margin recurved on stem leaves, dorsal leaf base extending across and beyond the stem, length of dorsal insertion ca. 1/3 of leaf width. Cells of leaf lobe isodiametrical to elongate, $25-40 \times 20-30$ $\mu \mathrm{m}$ in midleaf, becoming larger to the base and conspicuously smaller towards the margin, forming a broad, ill-defined leaf border of several rows of 

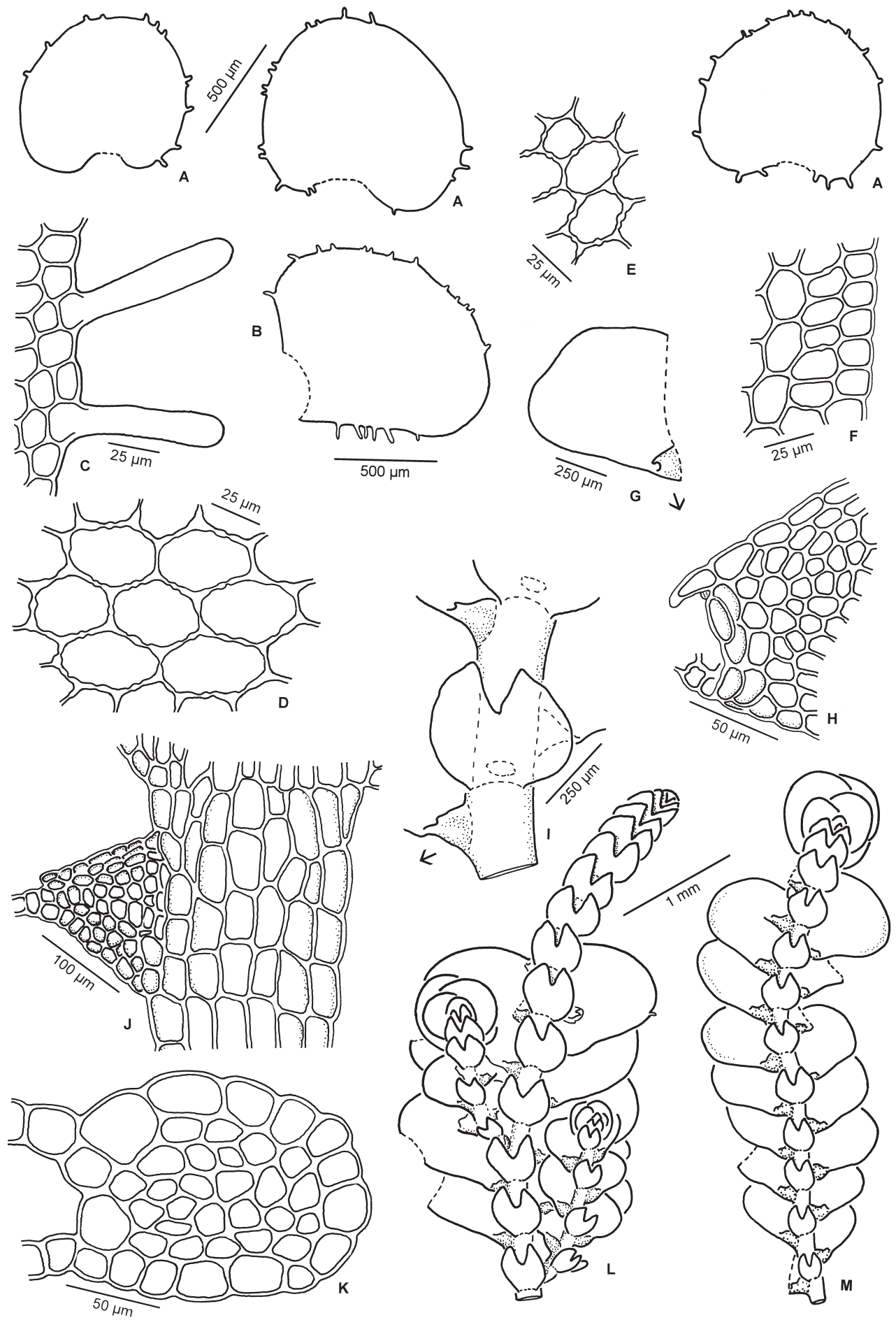

Fig. 1. Cheilolejeunea schiavoneana. A, B: Caducous leaf lobes. C: Margin of caducous leaf lobe with rhizoids. D: Median cells of caducous leaf lobe. E: Median cells of leaf lobe. F: Marginal cells of leaf lobe. G: Leaf. H: Apex of leaf lobule (detail of fig. G). I: Shoot sector. J: Stem and leaf lobule in situ. K: Cross section of stem. L: Habit, with flagelliform shoot at apex. M: Habit. (All drawn from the type). 
rather small cells, margin cells ca. 12-16 $\mu \mathrm{m}$ high; cell walls with conspicuous triradiate trigones and 0-2 rounded to elongate intermediate thickenings, cuticle smooth; oil bodies not observed; ocelli not seen. Lobules ovate, shortly flask-shaped, on stems $1 / 6-1 / 5 \times$ leaf length, on microphyllous branches ca. $2 / 3 \times$ leaf length, $0.15-0.3 \mathrm{~mm}$ long $\times$ 0.12-0.2 mm wide, strongly inflated, free margin incurved, not or very shortly continuing into the ventral leaf margin, lobule apex obliquely truncate, with a long and sharp tooth, the tooth, 25-40 $\mu \mathrm{m}$ long and $10 \mu \mathrm{m}$ wide , 2.5-4× longer than wide, \pm straight, with a conspicuously thickened tip; hyaline papilla in a small notch distal to the tooth; keel smooth and straight on stem leaves (arched and crenate on microphyllous branch leaves), forming an almost straight line with the ventral leaf margin; lobule cells much smaller than leaf cells, subisodiametrical, 12-20 $\mu \mathrm{m}$ long, walls with triradiate thickenings, free margin cells in the upper half of the lobule covered by a broad, colorless layer of thickening. Underleaves distant to contiguous, plane, broadly ovate, $0.3-0.5 \mathrm{~mm}$ long $\times$ 0.35-0.6 mm wide, $2-3 \times$ stem width, bifid to $1 / 2-3 / 5$, lobes broad, ca. $13-16$ cells wide at base, apex obtuse or narrowly rounded, incision rather widely $\mathrm{V}$-shaped, sinus narrowly rounded, margins plane, entire, sometimes bluntly angled in the middle, bases cuneate to rounded, insertion line curved; underleaf cells smaller than the leaf lobe cells, oil bodies and ocelli not observed; rhizoid disc small, rhizoids few, colorless.

Dioicous? (Gametoecia not seen). Vegetative reproduction by caducous leaf lobes produced on ascending, flagelliform prolongations of prostrate branches, the ascending shoots ca. 4-15 leaf cycles long, with tiny leaf lobules and densely imbricate, appressed to subsquarrose underleaves, shoot apex usually with a few closely appressed, undetached leaf lobes; caducous leaf lobes suborbicular to broadly ovate, slightly smaller than normal leaves, ca. $0.75-0.9 \mathrm{~mm}$ long $\times$ 0.75-1 mm wide, insertion line subtransverse, margin with 5-30 scattered rhizoids, the rhizoids short, (10-)20-80(-120) $\mu \mathrm{m}$ long; cells of caducous leaf lobes 35-65 × 20-30 $\mu \mathrm{m}$ in midleaf, as large as or somewhat larger than those of normal leaf lobe cells, not or scarcely larger at leaf base, smaller at the margin; ocelli not observed; gemmalings developing from leaf surface, 1-3 per leaf.
Distribution and habitat. Cheilolejeunea schiavoneana is only known from the type locality in submontane rainforest at ca. $1200 \mathrm{~m}$ in the Western Cordillera of Colombia, on the western slope of the Andes bordering the wet Pacific coastal lowland rainforests of the Chocó Department. The new species was growing in loose mats on branches in the forest canopy together with several other members of Lejeuneaceae, including Bryopteris filicina (Sw.) Nees, Ceratolejeunea cornuta (Lindenb.) Steph., Cyclolejeunea peruviana (Lehm. \& Lindenb.) A.Evans, Drepanolejeunea biocellata A.Evans, Lejeunea flava (Sw.) Nees, Lepidolejeunea cordifissa (Taylor) M.E.Reiner, L. involuta (Gottsche) Grolle, Microlejeunea acutifolia Steph., Stictolejeunea squamata (Willd.) Schiffn. and an undescribed species of the genus Rectolejeunea A.Evans (Gradstein, in prep.).

Observations. Cheilolejeunea schiavoneana is a member of the genus Cheilolejeunea (Lejeuneaceae subtribe Cheilolejeuneinae Gradst.) because of the lobule with a distal hyaline papilla (Fig. 1H). Within this genus, the new species stands out by the robust stems, being 5-6 cells wide across the ventral stem surface, the presence of numerous small, microphyllous branches, triradiate trigones and, especially, by vegetative reproduction by means of caducous leaf lobes falling off from small, upright flagelliform shoots. The caducous leaf lobes are somewhat smaller than normal leaf lobes and are typically broader than long, with a rather short, subtransverse insertion and numerous short rhizoids on the margins. The flagelliform shoots are largely devoid of lateral leaves except for the small, persistent lobules; in addition, a few undetached leaf lobes may be present at the tips of the shoots. The underleaves of the flagelliform shoots are densely imbricate due to shortening of the merophytes of the shoots. In contrast, underleaves on normal shoots are usely widely spatiated and distant.

Caducous leaf lobes are uncommon in the genus Cheilolejeunea; when present, they are always produced on normal leafy shoots (e.g. in C. adnata (Lehm.) Grolle, C. aneogyna (Spruce) A. Evans and C. caducifolia (Grolle \& Gradst.) Yet et al.), never on upright flagelliform shoots. Such specialized flagelliform shoots are quite characteristic of the genus Rectolejeunea (Reiner- 


\section{S. R. Gradstein and M. E. Reiner-Drehwald - New species of Cheilolejeunea}

Drehwald \& Grolle, 2012), but are unknown in Cheilolejeunea, and the new species was therefore initially believed to be an undescribed member of Rectolejeunea. However, the absence of ocelli, the leaf cells with trigones and, especially, the distal hyaline papilla clearly separate $C$. schiavoneana from Rectolejeunea. The latter genus is a member of Lejeuneaceae subtribe Lepidolejeuneinae Gradst. and phylogenetically quite distant from Cheilolejeunea (Heinrichs et al., 2015; Bechteler et al., 2016). We therefore suggest that the presence of vegetative reproduction by means of caducous leaf lobes produced on specialized flagelliform branches in C. schiavoneana may be interpreted as a case of parallel evolution between Rectolejeunea and Cheilolejeunea.

Within Cheilolejeunea, the new species seems to be most closely related to $C$. adnata, a species widespread in tropical America and type of the genus Cheilolejeunea; for descriptions see Evans (1906, as C. decidua [Spruce] A.Evans), Schuster (1980) and Gradstein \& Ilkiu-Borges (2009). The two species share several distinct features, such as: 1) smooth leaves with a rounded apex; 2) leaf cells with small, triradiate trigones and intermediate thickenings; 3) bottle-shaped lobules with a long and thin tooth, and the hyaline papilla positioned in a small notch distal to the tooth; 4) distant underleaves bifid to $1 / 2$ and with a cuneate base; 5) vegetative reproduction by caducous leaf lobes with short rhizoids on the margins. They clearly differ, however, in size, branching pattern, stem structure and vegetative reproduction; differences are shown in Table 1. The most striking differences are undoubtedly the more robust stems of $R$. schiavoneana with a 5-6 cells wide ventral merophyte, and caducous leaf lobes produced on upright flagelliform shoots.

Because of its similarity to $C$. adnata, $C$. schiavoneana may be placed in $C$. sect. Cheilolejeunea. The latter is a small group of about five species, including C. adnata (neotropical), C. larsenii Mizut. (pantropical), C. lineata Steph. (neotropical), and possibly C. albovirens (Hook.f. \& Taylor) E.A.Hodgs. (Australasia) and C. verrucosa Steph. (Asia) (Ye et al., 2015). Characters of this section include the long and thin lobule tooth, presence of a hyalodermis and absence of gynoecial innovations. Cheilolejeunea schiavoneana clearly differs from the members in this section by the robust stem and the peculiar flagelliform branches. As the material was sterile, absence of gynoecial innovation in $C$. schiavoneana could not be verified. We suggest that the phylogenetic relationships of this remarkable species be clarified based on fertile plants and DNA analysis.

Table 1. A comparison of Cheilolejeunea adnata and C. schiavoneana.

\begin{tabular}{|c|c|c|}
\hline & C. adnata & C. schiavoneana \\
\hline Plant width & $0.7-1.2 \mathrm{~mm}$ & $1.2-2.45 \mathrm{~mm}$ \\
\hline $\begin{array}{l}\text { Microphyllous } \\
\text { branches }\end{array}$ & absent & present \\
\hline Stem & $\begin{array}{l}85-120 \mu \mathrm{m} \text { thick; ca. } 7 \text { rows of } \\
\text { epidermal cells and } 10 \text { rows of } \\
\text { medullary cells }\end{array}$ & $\begin{array}{l}130-210 \mu \mathrm{m} \text { thick; } 11-15 \text { rows of epidermal } \\
\text { cells and } 20-25 \text { rows of medullary cells }\end{array}$ \\
\hline $\begin{array}{l}\text { Ventral merophyte on } \\
\text { stem }\end{array}$ & 2 cells wide & 5-6 cells wide \\
\hline Stem leaves & 0.6-0.7 mm long & 0.7-1.35 mm long \\
\hline Caducous leaf lobes & $\begin{array}{l}\text { as large as normal leaf lobes, } \\
\text { produced on normal shoots }\end{array}$ & $\begin{array}{l}\text { smaller than normal leaf lobes, produced } \\
\text { on specialized, upright flagelliform shoots }\end{array}$ \\
\hline Leaf cells & $\begin{array}{l}\text { with small triradiate trigones and } \\
\text { intermediate thickenings }\end{array}$ & $\begin{array}{l}\text { with small triradiate trigones and } \\
\text { intermediate thickenings }\end{array}$ \\
\hline Lobules & $\begin{array}{l}1 / 4-1 / 3 \times \text { leaf length, bottle-shaped, } \\
\text { with a long and sharp tooth }\end{array}$ & $\begin{array}{l}1 / 6-1 / 5 \times \text { leaf length, bottle-shaped, with a } \\
\text { long and sharp tooth }\end{array}$ \\
\hline Underleaves & $1.5-2 \times$ stem width & $2-3 \times$ stem width \\
\hline
\end{tabular}




\section{ACKNOWLEDgMENTS}

Fieldwork in the Cordillera Occidental of Colombia by the first author was supported by the National Geographic Society (grant \# 46 91-91 to J.-P. Frahm).

\section{Bibliography}

BECHTELER, J., G. E. LEE, A. SCHÄFER-VERWIMP, T. PÓCS, D. F. PERALTA, M. A. M. RENNER, H. SCHNEIDER \& J. HEINRICHS. 2016. Towards a monophyletic classification of Lejeuneaceae IV: reinstatement of Allorgella, transfer of Microlejeunea aphanella to Vitalianthus and refinements of the subtribal classification. Plant Syst. Evol. 302: 187201.

EVANS, A. W. 1906. Hepaticae of Puerto Rico VI. Cheilolejeunea, Rectolejeunea, Cystolejeunea and Pycnolejeunea. Bull. Torrey Bot. Club 33: 1-25.

FRAHM, J.-P. 1994. A contribution to the bryoflora of the Chocó region, Colombia. I. Mosses. Trop. Bryol. 9: 89-110.

GRADSTEIN, S. R. \& A. L. ILKIU-BORGES. 2009. Guide to the Plants of Central French Guiana. Part IV. Liverworts and Hornworts. Mem. N. Y. Bot. Gard. 76, 4: 1-140.

GRADSTEIN, S. R. \& J. URIBE M. 2016. Marchantiophyta. Pages 282-352 in R. Bernal, S.R. Gradstein \& M. Celis (eds.), Catálogo de plantas $y$ líquenes de Colombia. Universidad Nacional de Colombia Press, Bogotá.

HEINRICHS, J., K. FELDBERG, J. BECHTELER, A. SCHEBEN, A. CZUMAJ, T. PÓCS, H. SCHNEIDER \& A. SCHÄFER-VERWIMP. 2015. Integrative taxonomy of Lepidolejeunea. (Jungermanniopsida: Porellales): Ocelli allow the recognition of two neglected species. Taxon 64: 216-228.

ILKIU-BORGES, A. L. 2016. Prionolejeunea. Flora Neotropical Monograph 116: 1-131.

REINER-DREHWALD, M. E. \& R. GROLLE. 2012. Review of the genus Rectolejeunea (Lejeuneaceae, Marchantiophyta). Nova Hedwigia 95: 451-482.
SCHÄFER-VERWIMP, A. K. FELDBERG, S. DONG, H. VAN MELICK, D. F. PERALTA, A. R. SCHMIDT, H. SCHNEIDER \& J. HEINRICHS. 2014. Towards a monophyletic classification of Lejeuneaceae III: the systematic position of Leiolejeunea. Phytotaxa 170: $187-198$.

SCHUSTER, R. M. 1980. The Hepaticae and Anthocerotae of North America IV. Columbia Univ. Press, New York.

SÖDERSTRÖM, L., A. HAGBORG, M. VON KONRAT, S. BARTHOLOMEW-BEGAN, D. BELL, L. BRISCOE, E. BROWN, D. C. CARGILL, D. P. COSTA, B.J. CRANDALL-STOTLER, E. D. COOPER, G. DAUPHIN, J. J. ENGEL, K. FELDBERG, D. GLENNY, S. R. GRADSTEIN, X. L. HE, J. HEINRICHS, J. HENTSCHEL, A. L. ILKIU-BORGES, T. KATAGIRI, N. A. KONSTANTINOVA, J. LARRAIN, D. G. LONG, M. NEBEL, T. PÓCS, F. FELISA PUCHE, E. REINER-DREHWALD, M. A. M. RENNER, A. SASS-GYARMATI, A. SCHAFER-VERWIMP, J. G. SEGARRA MORAGUES, R. E. STOTLER, P. SUKKHARAK, B. M. THIERS, J. URIBE, J. VÁŇA, J. C. VILLARREAL, M. WIGGINTON, L. ZHANG \& R. L. ZHU. 2016. World checklist of hornworts and liverworts. PhytoKeys 59: 1-821.

WILSON, R., S. R. GRADSTEIN, H. SCHNEIDER \& J. HEINRICHS. 2007. Unravelling the phylogeny of Lejeuneaceae (Jungermanniopsida): evidence for four main lineages. Molec. Phylog. Evol. 43: 270-282.

YE, W., S. R. GRADSTEIN, J. A. SHAW, B. SHAW, B. C. HO, A. SCHÄFER-VERWIMP, T. PÓCS, J. HEINRICHS \& R. L. ZHU. 2015. Phylogeny and classification of Lejeuneaceae subtribe Cheilolejeuneinae (Marchantiophyta) based on nuclear and plastid molecular markers. Cryptog., Bryol. 36: 313-333.

Recibido el 1 de febrero de 2017, aceptado el 28 de marzo de 2017. 